\title{
HOW SOCIAL ARE ISLAMIC BANKS IN PAKISTAN?
}

\author{
Rafea Irfan \\ Student \\ Institute of Business Administration, Karachi, Pakistan \\ E-mail: rafiairfan1996@gmail.com
}

\begin{abstract}
Purpose: This research paper attempts to prove that social outcomes are one of the objectives of Islamic banks and tries to investigate whether social failure exists in the Islamic banking sector of Pakistan by assessing the social performance of Islamic banks against performance indicators of social outcomes.

Design/Methodology/ Approach: In this paper content analysis of annual reports of a sample of 4 Islamic conventional banks and 4 Islamic banking units functioning in Pakistan is conducted. The social outcomes that are attempted to be measured of the Islamic banks in this research paper are derived from social objectives present in literature, in addition to this, Kinder, Lydenberg, Domini Research, 17 Sustainable Development goals of the United Nations, five Environment Social Governance scorecards developed by Oikocredit which is a global cooperative and social investor group, and Analytics index of corporate social performance are used for the derivation of social outcomes.

Findings: Conventional Islamic banks in Pakistan are doing better than Islamic banking units on measures of social responsiveness.

Originality/Value: This research paper is based on the framework of the research paper "How social is Islamic banking" written on the Islamic banking sector of Indonesia by Luthfi Hamidi and Andrew C. Worthington.
\end{abstract}

Keywords: Islamic Banking, Business, Social Responsiveness, Corporate Social Responsibility, Corporate Social Performance.

JEL Classification Codes: G0, G2, P4, Q3.

\section{INTRODUCTION}

Islamic banking is a banking system present in the world that adheres to the principles of Islam. The Islamic Shariah provides guidance related to every aspect of human life such as economic, social, political, and spiritual. The word worship that is widely used in Islamic Shariah means faithful and diligent execution of duties and obligations as per Islamic principles. The Islamic Shariah is all about creating a just society and seeking God's blessings in this world and hereafter (Haniffa \& Hudaib, 2007).

Corporate social responsibility has been practiced by companies in the west for more than half a century. In Islamic banking, corporate social responsibility has a special place because it's a business contribution towards social reformation. CSR in Islamic banking is one of the essential elements that distinguish the capitalist system from the Islamic system. But in reality, Islamic banks are criticized for not fully adopting the Islamic moral economy. Islamic banks are accused 
of not working on the socioeconomic objectives that are aspirational and key objectives of the Islamic moral economy (Nor, Asutay, \& Mohd Amin, 2018).

To understand the social dimension of Islamic banks, some studies measure corporate social responsibility disclosure, Hassan and Harahap (2010) while others take into consideration social and ethical reporting (Haniffa \& Hudaib, 2007).

In one study by Hassan and Harahap, it was found out that the corporate social responsibility disclosure index of one bank out of a sample of seven banks was above average and it was concluded that corporate social responsibility is not considered important by Islamic banks (Hassan \& Harahap, 2010). In a study by Haniffa and Hudaib (2007), in which they tried to identify discrepancies that existed between communicated ethical identity, based on what is disclosed in the bank's annual reports, and ideal ethical identity, based on what is considered essential to disclose in Islamic framework of business. It was found out that out of a sample of seven banks, six are suffering from disparity. The dimensions along which major disparities exist are commitment to society, proper communication of the company's mission and vision, management of zakat and bank's contribution towards zakat, and charity (Haniffa \& Hudaib, 2007).

The Islamic finance and banking industry is a new phenomenon and has shown tremendous growth but a closer examination of this development and growth shows that Islamic banking and finance do not share the aspiration of Islamic economics. Islamic economics emphasizes a lot on social welfare. However, the prevailing literature indicates that these aspirational objectives are not so far achieved by the operational side of Islamic economics which is Islamic finance. Islamic economics aims to improve social justice and the human wellbeing of the society. It is a known truth that under no condition these two objectives can be achieved through economic incentives that are maximization of utility in Islamic or conventional banking. To rectify the failure of Islamic finance, which happened due to deviation from Islamic economics by giving huge importance to economic incentives, robust social justice principles are introduced into Islamic finance which means the addition of these principles into the operational side of Islamic economics (Asutay, 2007).

In an analysis by Hamidi and Worthington (2017), the actual social actions of the Islamic banks were measured by measuring the social responsiveness of the sample of the Islamic banks. The social actions that were taken into account were lending of benevolent loans (Qardh-alHasan), avoidance of any financing that can hurt society and the environment, and finally, the conduction of charity through zakat (Hamidi \& Warthington, 2017).

The analysis performed in the research paper of Hamidi and Worthington (2020) differs from previous studies in many ways. Firstly, in an attempt to measure the social responsibility of a bank, most studies, with exception of only a few, use content analysis with a quantitative dimension which means the use of certain words, or the number of pages or sentences. A construct will be given a score of one if present in the text otherwise zero. To balance this effect, qualitative evaluation was also performed in that study. Second, the Islamic banks use the instructions of the Accounting and Auditing Organization for Islamic Financial Institutions for social disclosure which is a non-profit organization that establishes Shariah standards for Islamic banks. Many studies are done by Haniffa and Hudaib (2007) and Hussan and Harahap (2010) to measure the Islamic banks' performance against dimensions such as strategy, governance, products, community, environment, employment, and R\&D. However, these studies do not take into account the piousness and devoutness of staff and management of Islamic banks. In the existing framework, religiosity was added because it had the potential to influence the bank's efforts towards social responsibility. Finally, the existing studies have only examined the social 
dimensions in only full-fledged Islamic banks, but in the study, Islamic rural banks and Islamic Banking units were also included. This provided an opportunity to see how social responsiveness varies across different institutional forms of Islamic banks (Hamidi \&Worthington, 2020).

This research paper will try to measure social dimensions measured by Hamidi and Worthington (2020) in their research paper of Islamic banks functioning in Indonesia. But the same social dimensions are used in this research paper to measure the social responsiveness of Pakistani Islamic Banks.

The structure of this research paper is as follows:

- The second section consists of a literature review describing Islamic banking and its societal objectives and aspirations.

- The third section consists of the methodology used to get the result.

- The fourth section is regarding findings.

- And, the final section is about the conclusion.

\section{LITERATURE REVIEW}

The religions followed by two-third of the world's population are Christianity, Islam, Hinduism, and Judaism. In all these four religions, interest-based lending (riba) is prohibited. Contrary to this, for more than 200 years, the financial system around the world are working on the principles of interest. Efforts have been made in the past and continued to happen till date against interest-based lending. These efforts are particularly made in the Islamic world, initiatives are taken to replace interest-based lending with profit and loss sharing. In this new system, lending and borrowing of money are replaced by the sale and lease of real assets. Is it necessary to replace the conventional financial system with a Shariah-compliant financial system? The financial crisis of 2007-2008 happened due to lack of adequate discipline in the financial system. The Profit and loss sharing system ensures greater discipline by making banks more careful in the lending process and making depositors more watchful for the bank's health (Chapra, 2007).

In Islamic finance, multiple contracts are available including Mudharabah and Musyarakah. Mudharabah is a partnership contract in which one party provides capital to the other party for business activity, contrary Musyarakah is a joint venture. Mudharabah and Musyarakah are different from conventional banking in many ways. They absorb unemployment, create new businesses, and finally save society from risky financial engineering. These two products are major products of Islamic banking. In some countries, these contracts constitute $90 \%$ of the financing (Vogel \& Hayes, 1998).

The objectives, operations, and activities of Islamic banks are based on Islamic principles and laws. These Islamic principles and laws are derived from the Holy Quran and Sunnah of the Prophet (P.B.U.H). The four fundamentals that govern the business of Islamic banks are discussed below.

Firstly, interest (riba) is prohibited in Islamic banking. In Islam, it is prohibited to make profit from an exchange of money for money.

Secondly, Gharar is prohibited in Islamic banking. Gharar means excessive and absolute risk or uncertainty in a business transaction.

Thirdly, Islamic banking prohibits Maisir. It means unlawful, unethical, socially irresponsible activities. Islamic banking does not finance businesses that are involved in nonIslamic activities.

Finally, Islamic banks make sure that financial transactions are directly or indirectly linked to real economic transactions (Mbawuni \& Nimako, 2018). 
The services of Islamic banks also include zakat and Qardh al-hasan. The sole purpose of this service is to help the poor individuals of society and alleviate them from poverty. Islamic banks are still accused of not delivering on their commitment to social responsibility. The failure in demonstrating any good results indicates that Islamic banking does not affect the lives of poor individuals of the society and these banks prioritize the better-off individuals (Asutay \& Zaman, 2009).

Tulsain and Pandey (2008) categorize the business objectives into four categories which are also mentioned by Hamidi and Worthington (2020) in their study: economic, social, human, and national (Tulsain \& Pandey, 2008). They further discussed the major social objectives of the business that are:

- To supply the desired quality of products.

- To avoid any antisocial and unfair trade practices.

- To generate employment

- To work for the welfare of employees.

- To avoid pollution.

- To contribute towards the welfare of society (Tulsain \& Pandey, 2008). Islamic banks are expected to work to achieve social objectives, contrary to just working to achieve profit maximization. Otherwise, if banks fail to bring social welfare to society, some may conclude that converting a bank into a state-owned enterprise is the only way to avoid market failure and to bring about economic development and welfare to the society (Hamidi \& Worthington, 2020).

There are two opinions among scholars regarding social objectives. One side believes that Islamic banks should function as a normal business enterprise and only their operations should comply with Shariah, which means reliance on only zakat for social contribution without putting the owner's fund at risk (Lewis \& Algaoud, 2001). The other side holds the view that Islamic banking should promote an economic system that supports the development of a society that is fair and just (Naqvi, 2016).

Hamidi and Worthington (2020) also argued that the social responsiveness of Islamic banks should include objectives related to the creation of value-added, training programs, rehabilitation programs, more exports than imports, and economic development (Hamidi \& Worthington, 2020).

\section{CORPORATE SOCIAL RESPONSIBILITY IN ISLAMIC BANKING}

Commission of European communities defines Corporate Social Responsibility as an interrelation between an enterprise as a whole and a society. Through Corporate social responsibilities, businesses include environmental and societal concerns into their business operations, and in their interaction with stakeholders (European Commission. Directorate-General for Employment, 2001).

Carroll (2004) presented the pyramid of global Corporate social responsibility and performance model which comprises of four main pillars: economics (to be profitable), legal (to obey the law), ethical (to follow ethical business practices), and finally philanthropic (to be a good corporate citizen) (Carroll, 2004).

Kinder, Lydenberg, Domini Research and Analytics (KLD) measures the corporate social responsibility of an enterprise against eight dimensions which are related to employees, business relationship with community, environment, product, treatment of minorities and women, military contract, nuclear power, and involvement in South Africa (Hamidi \& Worthington, 2020). 
There is very limited literature available that discusses the relationship between religion and management. A study conducted by Ibrahim, Howard, and Angelidis tries to determine the relationship between the degree of religiosity of a person and his corporate social responsibility orientation. The statistical analysis of surveys conducted for this study showed that the religiosity of a person does have an impact on the economic, ethical, and responsibility of business (Ibrahim, Howard, \& Angelidis, 2008).

The concept of Corporate social responsibility in Islam is different from the concept that prevails in the West. There are only a few studies conducted to investigate the CSR practices of Islamic banks. Maali, Casson, and Napier (2006) conducted a study and used a disclosure index to access the social reporting of 29 Islamic banks in 16 countries. It was revealed that social reporting by these banks was much less than expected. Banks that are required to pay zakat do more social disclosure than the banks which are not required to pay zakat. It was also revealed that much of the socially disclosed information was related to zakat. Zakat is one of the basic five pillars of Islam and it is not a surprise that banks that are paying zakat want to show it as they are complying with Islamic principles. This study also revealed that social issues are not that much of a concern for Islamic banks. One of its reason can be that majority of the Islamic banks are operating in less developed countries where social issues related to the environment are given less importance (Maali, Casson, \& Napier, 2006).

Islamic banks should take initiatives to reduce poverty in society through direct measures or indirect measures. To improve their social responsiveness, Islamic banks can use their funds to support programs that aim to build human resources such as providing scholarships and building a library. These indirect efforts help the poor individuals to get an education, to improve their skill set, and to improve their standard of living (Hamidi \& Worthington, 2020).

Another option for Islamic banks is to allocate their funds to disadvantaged groups or women. BTPN Syariah, a large Indonesian bank has allocated its funds to finance around five million women who all are "unbanked" (Hamidi \& Worthington, 2020).

Islamic banks should also work for the sustainability of the environment. Sustainable development is a way of meeting the needs of this generation without compromising the resources that are required to meet the needs of future generations. Overconsumption of resources is prohibited in Islam (Bidabad, 2019)

Another possible way to improve social responsiveness is through channeling. In this initiative, Islamic banks transfer their funds to Islamic rural banks, then these rural banks act as an agent in the disbursement of funds to its end users. Some of the benefits of this method are: Cost is reduced, human resource is not needed to administer the transaction and to monitor the financing, and another benefit is that social objectives are effectively achieved without disturbing the business operations of main Islamic bank (Hamidi \& Worthington, 2020).

Islamic banks can also improve their social objectives by improving on their conventional social features such as zakat which is obligatory almsgiving, Qardh al- hasan which is a benevolent loan, and finally cash waqf that is an endowment in the form of money (Hamidi \& Worthington, 2020).

This research paper aims to access the efforts of Pakistani Islamic banks in this regard.

\section{METHODOLOGY}

In this study, the same method is used as by Hamidi and Worthington (2020) in their research paper to measure the social responsiveness of Islamic banks in Pakistan. For our analysis, published annual reports of Pakistani Islamic banks are used. A typical annual report consists of the following parts: 
- Organizational overview.

- Unconsolidated Financial Statement.

- Corporate Governance.

- Consolidated Financial Statement.

- Others.

All parts of the reports are used to determine the social outcomes of the banks. If the information is unavailable in the annual report, following the study of Kamla and Rammala (2013), banks' websites are used to get information regarding their financial and social activities.

There are two types of Islamic banks in Pakistan. One is Islamic commercial banks that are fullfledged Islamic banks and the other is Islamic banking units that are Islamic banking windows of conventional banks. The sample for this study consists of 8 Islamic banks functioning in Pakistan: 4 are commercial Islamic banks and 4 are Islamic business units.

The sample of commercial Islamic banks consists of Bank Islami Pakistan, Meezan bank, Faysal bank, and Islamic commercial bank (Al Baraka). The sample of Islamic banking units consists of Bank Alfalah Islamic, HBL Islamic banking, UBL Islamic banking, and Allied bank (Sirat Islamic Banking).

We have used content analysis to investigate the social outcomes of these Islamic banks which are mainly in two forms. For content analysis, We have analyzed textual data. The most difficult step of content analysis was to develop categories to classify the textual data.

I have used directed content analysis which required theories to identify categories to do the initial coding.

We have used categories created by Hamidi and Worthington (2020) in their research paper. For creating categories, they used prevailing literature regarding social objectives and disclosure by Islamic banks, the KLD index of corporate performance, the 17 Sustainable development Goals by the United Nations, and the five Environmental Social Governance (ESG) developed by a worldwide cooperative and social investor group.

Table 1. Social performance indicators for Islamic banks.

\begin{tabular}{|c|c|c|c|}
\hline Islamic Perspective & KLD indices & $\begin{array}{l}\text { The } 5 \text { ESG } \\
\text { Scorecard }\end{array}$ & The 17 SDGS \\
\hline 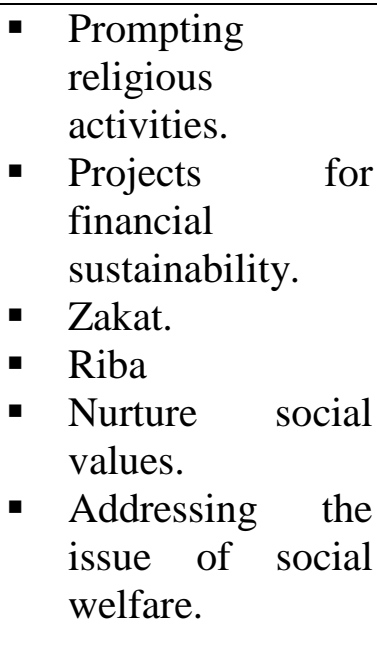 & $\begin{array}{l}\text { Employees. } \\
\text { - } \text { Communities. } \\
\text { - } \text { Corporate } \\
\text { governance. } \\
\text { - } \text { Product quality, } \\
\text { and safety. } \\
\text { Diversity and } \\
\text { Equality. } \\
\text { - Environmental } \\
\text { - Sustainability. }\end{array}$ & 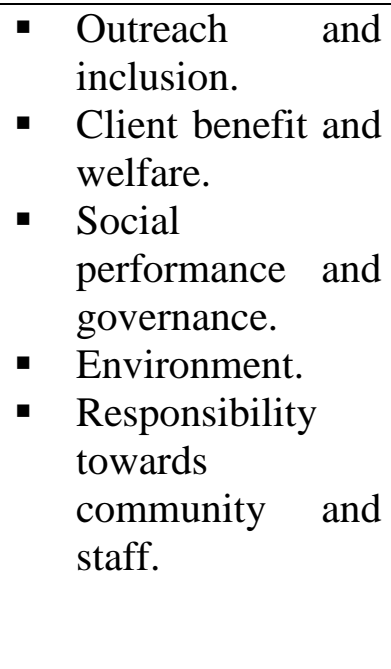 & 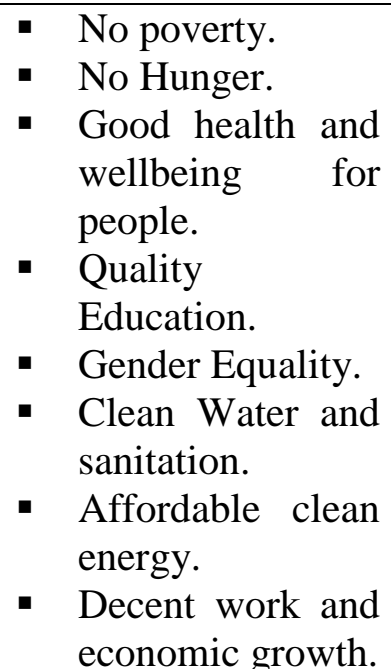 \\
\hline
\end{tabular}




\begin{tabular}{|l|l|l|l|}
\hline & & & $\begin{array}{l}\text { Reduced } \\
\text { inequalities. } \\
\text { Peace, justice, } \\
\text { and strong } \\
\text { institution. }\end{array}$ \\
\hline
\end{tabular}

Using the above table Hamidi and Worthington (2020) created 6 categories, each contains multiple constructs to measure the social objectives of Islamic banks which are as follow:

- Religiosity contains constructs such as zakat, Qardh al-hasan, riba, and encouraging spirituality.

- Environment contains constructs such as preserving the environment, managing green offices, and green financing.

- Social ends contain constructs such as encouraging education, training, improvement in quality, and economic empowerment.

- Governance contains constructs such as vision and mission, prevention of corruption and fraud, proper handling complaints from customers, and ethics compliance and staff compliance.

- Management of employees by Islamic banks includes constructs such as rewards, the opportunity of training, education for employees, and equal opportunity of work for men and women.

- Customer orientation contains constructs such as discounts for customers, special financial products for disadvantaged groups and women, and serving unserved areas.

The Appendix at the end of the research paper spells out how I have used keywords to identify and then to code the above-mentioned constructs.

No content analysis is without its challenges of reliability and validity. The issue of reliability may occur due to the vagueness of meaning and definition, to solve the reliability issue, like Hamidi and Worthington (2020) I have used three coders to score the contracts. Validity means the extent to which results are consistent with existing theories, to avoid this problem, I have used definitions from the literature of corporate social responsibility and performance, and Islamic banking.

Like Hamidi and Worthington (2020), I have used an equal-weighted index to measure the social outcomes of each bank against 6 categories.

$$
\sum_{t=1}^{n_{j}} X_{i j} / n_{j}
$$

$\mathrm{n}=$ number of constructs revealed by each Islamic bank.

$\mathrm{X}_{\mathrm{ij}}=2$ if construct is qualitative as well as quantitative.

$\mathrm{X}_{\mathrm{ij}}=1$ if the construct is qualitative.

$\mathrm{X}_{\mathrm{ij}}=0$ if construct is neither qualitative nor quantitative.

To understand the coding of each construct, consider the construct "preventing corruption and fraud". Firstly, search keywords "corruption" and "fraud" in the annual report of the given Islamic bank. If your search shows no explicit concept of dealing with corruption and fraud, allot a 0 on this construct. If your search shows an explicit concept of dealing with corruption and fraud, allot a 1. If your search shows explicit concepts of dealing with fraud and corruption, the establishment of anti-fraud division and finally reporting of fraud allot 2.

Four category rating scale developed by Carroll (2004), Wartick and Cochran (1985), and Clarkson (1995) which is further modified by Hamidi and Worthington (2017) to rank the social 
responsiveness of each Islamic bank. Four rating categories are reactive, defensive, accommodative, and proactive.

\section{RESULT}

To access the social responsiveness of banks, like Hamidi and Worthington (2020) in this study the "RDAP scale" is used which is as follow:

Table 2. RDAP scale to access social responsiveness of Islamic banks.

\begin{tabular}{|l|l|l|l|}
\hline Achievement & Rating & Strategy & Performance \\
\hline $0-40 \%$ & Reactive & Bank is denying its responsibility. & Bank is doing less than required. \\
\hline $41-50 \%$ & Defensive & $\begin{array}{l}\text { Bank is admitting its responsibility } \\
\text { and fighting it. }\end{array}$ & Bank is at least that is required. \\
\hline $51-60 \%$ & Accommodative & Bank is accepting its responsibility. & Bank is doing all that is required. \\
\hline $61-100 \%$ & Proactive & $\begin{array}{l}\text { Bank is anticipating its } \\
\text { responsibility }\end{array}$ & $\begin{array}{l}\text { Bank is doing more than is } \\
\text { required }\end{array}$ \\
\hline
\end{tabular}

Table 3. Social outcome ratings.

\begin{tabular}{|l|l|l|l|l|}
\hline & 2020 & 2019 & $\%$ Change & Rating \\
\hline Islamic Commercial Banks & & & & \\
\hline Meezan bank. & 73.80952 & 66.66667 & 10.71428571 & $\mathrm{P}$ \\
\hline Bank Islami Pakistan. & 57.14286 & 57.14286 & 0 & $\mathrm{~A}$ \\
\hline Faysal bank. & 47.61905 & 47.61905 & 0 & $\mathrm{D}$ \\
\hline Islamic Commercial bank. & 57.14286 & 54.7619 & 4.347826087 & $\mathrm{~A}$ \\
\hline Islamic Banking Unit & & & & \\
\hline HBL. & 52.38095 & 52.38095 & 0 & $\mathrm{~A}$ \\
\hline UBL. & 47.61905 & 47.61905 & 0 & $\mathrm{D}$ \\
\hline Allied bank. & 57.14286 & 61.90476 & -7.69230769 & $\mathrm{~A}$ \\
\hline Alfalah bank. & 52.38095 & 57.14286 & -8.33333333 & $\mathrm{~A}$ \\
\hline
\end{tabular}

Only one bank out of a sample of 8 banks is doing more than what is required with $79.80 \%$ which is an Islamic commercial bank and has shown improvement in social responsiveness of $10.71 \%$. from the previous year. Two of the Islamic banks, Bank Islami Pakistan and Islamic Commercial bank, are doing all that is required. One of the Islamic banks, Faysal bank is defensive is doing the least that is required.

Most of the Islamic Banking Units are accommodative and doing all that is required.

\section{CONCLUSION}

The content analysis of this paper shows that Islamic commercial banks are better than Islamic banking units of commercial banks in social responsiveness.

In all types of Islamic banks, the majority of them are accommodative and are doing what is required of them. 


\section{REFERENCES}

Asutay, M., \& Zaman, N. (2009). Divergence between aspirations and realities of Islamic economics: A political economy approach to bridging the divide. IIUM Journal of Economics and Management, 17(1), 73-96.

Asutay, M. (2007). Conceptualisation of the second best solution in overcoming the social failure of Islamic finance: Examining the overpowering of homoislamicus by homoeconomicus. IIUM Journal in Economics and Management, 15(2), 167-195.

Bidabad, B. (2019). Overconsumption in ethic economics and sustainable development. International Journal of Islamic Business \& Management, 3(2), 42-51.

Carroll, A. B. (2004). Managing ethically with global stakeholders: A present and future challenge. Academy of Management Perspectives, 18(2), 114-120.

Chapra, M. U. (2007). The case against interest: Is it compelling? Thunderbird International Business Review, 49(2), 161-186.

European Commission. Directorate-General for Employment. (2001). Promoting a European framework for corporate social responsibility. Office for Official Publications of the European Communities.

Hamidi, M. L., \& Worthington, A. C. (2017). Islamic banking plus social banking equals Islamic social banking: an equation in the making. Banking: Services, Opportunities and Risks: Nova Science Publishers, Inc.

Hassan, A., \& Harahap, S. S. (2010). Exploring corporate social responsibility disclosure: the case of Islamic banks. International Journal of Islamic and Middle Eastern Finance and Management.

Hamidi, L., \& Worthington, A. C. (2020). How social is Islamic banking? Society and Business Review, 51-70.

Haniffa, R., \& Hudaib, M. (2007). Exploring the ethical identity of Islamic banks via communication in annual reports. Journal of business Ethics, 76(1), 97-116.

Ibrahim, N. A., Howard, D. P., \& Angelidis, J. P. (2008). The relationship between religiousness and corporate social responsibility orientation: are there differences between business managers and students? Journal of Business Ethics, 78(1), 165-174.

Lewis, M. K. \& Algaoud, L. M. (2001). Islamic Banking. Edward Elgar: Cheltenham.

Maali, B., Casson, P., \& Napier, C. (2006). Social reporting by Islamic banks. Abacus, 42(2), 266289. 
Mbawuni, J., \& Nimako, S. G. (2018). Muslim and non-Muslim consumers' perception towards introduction of Islamic banking in Ghana. Journal of Islamic Accounting and Business Research.

Nor, S. M., Asutay, M., \& Mohd Amin, S. I. (2018). Corporate Social Responsibility Practiced by the Malaysian Islamic Banks: A Study on the Islamic Moral Economy. International Journal of Business \& Management Science, 8(2).

Naqvi, S. N. H. (2016). Perspectives on morality and human well-being: A contribution to Islamic economics (Vol. 24). Kube Publishing Ltd.

Tulsain, P., \& Pandey, V. (2008). Business Organization and Management. New Delhi: Pearson Education.

Vogel, F.E. \& Hayes, S.L. (1998). Islamic Law and Finance: Religion, Risk, and Return. Boston: Kluwer Law International.

\section{NOTES}

After searching keywords related to specific constructs, assign value 0 if no specific policy is found, assign 1 if a particular policy exists, and assign 2 if a particular policy exists and reporting is found in annual reports of banks.

\section{Appendix A: Dimensions}

\section{APPENDICES}

Same dimensions and keywords are taken as by Hamidi and Worthington (2020) in their research paper.

\section{Religiosity}

\begin{tabular}{|l|l|}
\hline Constructs & Keywords \\
\hline Zakat. & Zakat and infaq. \\
\hline Qardh-al-hasan. & Qardh-al-hasan. \\
\hline Riba. & Riba and Interest. \\
\hline Encouraging spirituality. & Morning prayer, Zuhar prayer, and Quran classes. \\
\hline
\end{tabular}

\section{Environment}

\begin{tabular}{|l|l|}
\hline Constructs & Keywords \\
\hline $\begin{array}{l}\text { Environmental } \\
\text { awareness. }\end{array}$ & $\begin{array}{l}\text { Environmental awareness seminars, Reforestation, and } \\
\text { Reducing the use of plastic. }\end{array}$ \\
\hline Greenhouse. & Water, energy, and Material use. \\
\hline Green financing. & $\begin{array}{l}\text { Financing the treatment of water, organic food, and } \\
\text { recycling of plastic. }\end{array}$ \\
\hline
\end{tabular}




\section{Community}

\begin{tabular}{|l|l|}
\hline Constructs & Keywords \\
\hline Community education and training. & $\begin{array}{l}\text { Community training, education, and } \\
\text { scholarships. }\end{array}$ \\
\hline Community Quality improvement. & Natural disaster and health services. \\
\hline $\begin{array}{l}\text { Community economic } \\
\text { empowerment. }\end{array}$ & $\begin{array}{l}\text { Support local businesses, people, and local } \\
\text { workers. }\end{array}$ \\
\hline
\end{tabular}

\section{Governance}

\begin{tabular}{|l|l|}
\hline Constructs & Keywords \\
\hline Vision/ mission statement. & Social objectives. \\
\hline Prevent corruption and fraud. & Fraud and corruption. \\
\hline Handling customer complaints. & Customer complaints. \\
\hline Ethics and staff compliance. & Code of Ethics. \\
\hline
\end{tabular}

\section{Employees}

\begin{tabular}{|l|l|}
\hline Constructs & Keywords \\
\hline Reward for employees. & $\begin{array}{l}\text { Ownership of company's shares and Employees } \\
\text { reward. }\end{array}$ \\
\hline Equality in work opportunities. & Working Equality and Equal work opportunities. \\
\hline Training for employees. & $\begin{array}{l}\text { Workshops, training programs, and learning } \\
\text { programs. }\end{array}$ \\
\hline
\end{tabular}

\section{Client}

\begin{tabular}{|l|l|}
\hline Constructs & Keywords \\
\hline Serving unserved area. & Rural services. \\
\hline Diversified Financial products. & Women and disadvantaged groups. \\
\hline Discounts. & Discounts and speed up payment. \\
\hline
\end{tabular}

\section{Copyrights}

Copyright for this article is retained by the author(s), with first publication rights granted to the journal. This is an open-access article distributed under the terms and conditions of the Creative Commons Attribution license (http://creativecommons.org/licenses/by/4.0/) 